\title{
DETERMINATION OF THE MINERAL CONTENT OF SPICES BY ICP-OES
}

\author{
Saša Savić ${ }^{*}$, Sanja Petrović ${ }^{1}$, Mirjana Petronijević ${ }^{2}$, Aleksandra Cvetanović ${ }^{3}$, \\ Živomir Petronijević ${ }^{1}$ \\ (ORIGINAL SCIENTIFIC PAPER) \\ 1 University of Niš, Faculty of Technology, Leskovac, Serbia \\ UDC 664.5:661.8:543.42 \\ 2 University of Novi Sad, Faculty of Sciences, Department of Chemistry, Biochemistry and Environmental Protection, Novi Sad, Serbia \\ ${ }^{3}$ Faculty of Technology, University of Novi Sad Novi Sad, Serbia
}

Spices represent all edible plant parts used for food flavouring or colouring including fruits, roots, seeds, peels or vegetable substances. The objective of this study was to determine the elemental composition (Ag, Al, B, Ba, Bi, Ca, Cd, Co, Cr, Cu, Fe, In, K, Li, Mg, Mn, Na, Ni, Pb, Sr, TI and $\mathrm{Zn}$ ) of selected spices available in the local markets on Serbian territory. The presence of heavy metals in spices is of particular importance because this could result in the accumulation of these elements in human organs, which further might cause different health problems. The analysed spice samples were curcuma, star anise, cinnamon, ginger, coriander, cardamom, sesame, black pepper, chilli and curry. The preparation of the samples was done by wet digestion. The concentrations of elements after digestion were determined by Inductively Coupled Plasma - Optical Emission Spectrometry (ICP-OES). In the group of spices macroelements, from all examined elements the calcium concentration was the highest $(182.25-3968.79 \mathrm{mg} / \mathrm{kg})$, about $83 \%$. From the heavy metals group, aluminium was most present in the range of $0.0-10.78 \mathrm{mg} / \mathrm{kg}$, while cadmium and nickel were detected in almost negligible amounts.

Keywords: Spices, Minerals, ICP-OES

\section{Introduction}

Spices include fruits, roots, seeds, peels or vegetable substances [1]. The specific ways of using spices are significantly different among cultures and countries. They were primarily used in religious rituals, medicine, cosmetics, perfumery and as the addition to the human nutrition diet. The discovery of medicinal effects of spices significantly increased their use in most parts of the world including Europe [2-7]. Due to antioxidant, antimicrobial, diabetic, antiinflammatory and anti-hypersensitive properties, spices are used for medicinal proposes [8,9]. On the other side, spices in food play an important role in health, partially as a nutrients source.

Mineral nutrients are interrelated and balanced against each other in human physiology. For instance, calcium, sodium, magnesium and phosphorus are included in the body fluid regulation. Inadequate mineral intake generally produces deficiency symptoms as anemia, impaired healing of wounds, severe diarrhea and a chronic renal failure $[10,11]$. But, although spices represent a good source of nutrients, sometimes they might possess toxic compounds or accumulated heavy metals that originate from the production or processing and storage conditions. Heavy metals beyond the permissible limits could effects the human health and may lead to illness of a human fetus, preterm labor and mental retardation in children, while adults may suffer from fatigue, high blood pressure and kidney troubles. The use of heavy metals contaminated spices in human nutrition could result in accumulation of these elements in human organs, which further might cause different health problems [12]. For these reasons, the interest for harmful metals present in food has been increased in the last two decades [13,14].

In the past, scientists made an effort to determine the presence of macro- and microelements in spices that originated from all parts of the world. Several scientists have investigated the composition of Indian spices in term of their volatile oils and vitamins contents $[15,16]$, as well as chemical and toxic constituents. Ila and Jagam (1980) have also reported about 24 certain elements in six Indian spices [17]. Abou-Arab and Abou-Donia (2000) have determined heavy metal contaminants in Egyptian spices [18]. The methods that were previously used were either expensive or did not allow simultaneous estimation of the concerned micro minerals. Inductively coupled plasma with optical emission spectrometry (ICP-OES) is a well-established method for multi elemental analysis and determination of isotope ratios. This method allows a simultaneous analysis of a wide range of trace elements in the sample and has been successfully applied in this study [19]. The aim of this study was to determine the elemental composition (Ag, Al, B, Ba, $\mathrm{Bi}, \mathrm{Ca}, \mathrm{Cd}, \mathrm{Co}, \mathrm{Cr}, \mathrm{Cu}, \mathrm{Fe}, \mathrm{In}, \mathrm{K}, \mathrm{Li}, \mathrm{Mg}, \mathrm{Mn}, \mathrm{Na}, \mathrm{Ni}, \mathrm{Pb}$, $\mathrm{Sr}, \mathrm{Tl}$ and $\mathrm{Zn}$ ) of selected spices available in local markets on Serbian territory by using an inductively coupled plasma with optical emission spectrometry (ICP-OES). The con-

\footnotetext{
*Author address: Saša Savić, Faculty of Technology, Leskovac, University of Niš,

Bulevar Oslobođenja 124, 16000 Leskovac, Serbia

E-mail: sasa.savic@tf.ni.ac.rs

The manuscript received: December, 20, 2018

Paper accepted: March, 13, 2019.
} 
centrations of the investigated minerals were compared with the recommended values by the international organizations as FAO and WHO. The generated data might be used for the inorganic minerals daily intake planning i.e. a nutritional diet.

\section{Experimental part}

\section{ICP-OES analysis}

In order to estimate the content of the concentrations of macro- and micro elements, the calibration standards were prepared. Multistandard IV - standard solution (Merck), which contained $\mathrm{Ag}, \mathrm{Al}, \mathrm{B}, \mathrm{Ba}, \mathrm{Bi}, \mathrm{Ca}, \mathrm{Cd}, \mathrm{Co}, \mathrm{Cr}, \mathrm{Cu}, \mathrm{Fe}$,
In, K, Li, Mg, Mn, Na, Ni, Pb, Sr, Tl and Zn at the concentration of $1000 \mathrm{mg} / \mathrm{kg}$ was used for the preparation of calibration solutions. Distilled water, purified by Fisher Chemical (HPLC grade) was used for the dilution of the standard solution, as well as for the dilution of spices samples. The preparation of standard solutions was performed by diluting the standard, so that the concentrations of standards for the calibration charts were in the range of expected test elements concentrations. The carrier gas was Argon 5.0 (99.999\% purity). Table 1 shows the wavelength detection of each element in the samples, a correlation coefficient $\left(R^{2}\right)$, the limit of detection (LOD), as well as the range of linearity.

Table 1. Calibration parameters: $\lambda, n m ; R^{2} ; L D(\mu g / L)$ and the range of linearity $(\mu g / L)$.

\begin{tabular}{|c|c|c|c|c|}
\hline Element & $\begin{array}{c}\text { Detection } \\
\text { wavelength }(\mathrm{nm})\end{array}$ & $\begin{array}{l}\text { Correlation coefficient } \\
\qquad\left(R^{2}\right)\end{array}$ & $\begin{array}{l}\text { Limit of } \\
\text { detection } \\
\left(\mu \mathrm{g} / \mathrm{dm}^{3}\right)\end{array}$ & $\begin{array}{l}\text { Linearity range } \\
\qquad\left(\mathrm{mg} / \mathrm{dm}^{3}\right)\end{array}$ \\
\hline $\mathrm{Ag}$ & $\begin{array}{l}224.641 \\
328.068\end{array}$ & $\begin{array}{l}0.99993 \\
0.99995\end{array}$ & 0.39 & $\begin{array}{l}1.45 \times 10^{-2}-12.00 \\
3.99 \times 10^{-4}-12.00\end{array}$ \\
\hline $\mathrm{Al}$ & $\begin{array}{l}167.078 \\
394.401\end{array}$ & $\begin{array}{l}0.99985 \\
0.99998\end{array}$ & $7.6 \times 10^{-2}$ & $\begin{array}{c}7.6 \times 10^{-5}-2.40 \\
1.55 \times 10^{-3}-12.00\end{array}$ \\
\hline B & $\begin{array}{l}182.641 \\
249.773\end{array}$ & $\begin{array}{l}0.99999 \\
0.99999\end{array}$ & 6.43 & $\begin{array}{l}7.37 \times 10^{-3}-12.00 \\
6.43 \times 10^{-3}-12.00\end{array}$ \\
\hline $\mathrm{Ba}$ & 233.527 & 0.99995 & 0.183 & $1.83 \times 10^{-4}-12.00$ \\
\hline $\mathrm{Bi}$ & $\begin{array}{l}190.241 \\
223.061\end{array}$ & $\begin{array}{l}0.99991 \\
0.99996\end{array}$ & 3.53 & $\begin{array}{l}3.53 \times 10^{-3}-12.00 \\
3.68 \times 10^{-3}-12.00\end{array}$ \\
\hline $\mathrm{Ca}$ & $\begin{array}{l}183.801 \\
396.847\end{array}$ & $\begin{array}{l}0.99995 \\
0.99946\end{array}$ & 2.14 & $\begin{array}{c}1.6-480.00 \\
2.14 \times 10^{-3}-2.41\end{array}$ \\
\hline $\mathrm{Cd}$ & 214.438 & 0.99994 & 0.127 & $1.27 \times 10^{-4}-12.00$ \\
\hline Co & 228.616 & 0.99980 & 0.327 & $3.27 \times 10^{-4}-12.00$ \\
\hline $\mathrm{Cr}$ & 283.563 & 0.99998 & 0.435 & $4.35 \times 10^{-4}-12.00$ \\
\hline $\mathrm{Cu}$ & $\begin{array}{l}224.700 \\
324.754\end{array}$ & $\begin{array}{l}0.99999 \\
0.99999\end{array}$ & 0.259 & $\begin{array}{l}9.07 \times 10^{-4}-12.00 \\
2.59 \times 10^{-4}-12.00\end{array}$ \\
\hline $\mathrm{Fe}$ & 259.941 & 0.99997 & 0.118 & $1.18 \times 10^{-4}-12.00$ \\
\hline $\ln$ & 325.609 & 1.00000 & 4 & $4 \times 10^{-3}-12.00$ \\
\hline $\mathrm{K}$ & $\begin{array}{l}404.721 \\
766.491\end{array}$ & $\begin{array}{l}0.99998 \\
0.99999\end{array}$ & 0.378 & $\begin{array}{c}0.798-300.00 \\
3.78 \times 10^{-4}-1.20\end{array}$ \\
\hline $\mathrm{Li}$ & $\begin{array}{l}323.261 \\
670.780\end{array}$ & $\begin{array}{l}1.00000 \\
0.99997\end{array}$ & $5.75 \times 10^{-2}$ & $\begin{array}{c}7.98 \times 10^{-2}-12.00 \\
5.75 \times 10^{-5}-1.20\end{array}$ \\
\hline $\mathrm{Mg}$ & $\begin{array}{l}279.553 \\
285.213\end{array}$ & $\begin{array}{l}0.99997 \\
0.99994\end{array}$ & 0.115 & $\begin{array}{c}1.15 \times 10^{-4}-6.04 \\
4.03-120.00\end{array}$ \\
\hline $\mathrm{Mn}$ & 257.611 & 0.99992 & $3.57 \times 10^{-2}$ & $3.57 \times 10^{-5}-12.00$ \\
\hline $\mathrm{Na}$ & $\begin{array}{l}330.237 \\
598.592\end{array}$ & $\begin{array}{l}0.99994 \\
0.99989\end{array}$ & 4.75 & $\begin{array}{c}7.98-480.00 \\
4.75 \times 10^{-3}-12.00\end{array}$ \\
\hline $\mathrm{Ni}$ & 231.604 & 0.99994 & 0.474 & $4.74 \times 10^{-4}-12.00$ \\
\hline $\mathrm{Pb}$ & 220.353 & 0.99998 & 1.78 & $1.78 \times 10^{-3}-12.00$ \\
\hline $\mathrm{Sr}$ & 407.771 & 0.99998 & $6.23 \times 10^{-3}$ & $6.23 \times 10^{-6}-2.41$ \\
\hline $\mathrm{Tl}$ & 190.864 & 0.99998 & 1.72 & $1.72 \times 10^{-3}-12.00$ \\
\hline $\mathrm{Zn}$ & 213.856 & 0.99997 & $8.2 \times 10^{-2}$ & $8.2 \times 10^{-5}-12.00$ \\
\hline
\end{tabular}

Table 2. Analysed spices characteristics

\begin{tabular}{cccc}
\hline Common name & Botanical name & Family & Used parts \\
Cardamon & Elettaria cardamomum & Zingiberaceae & seed \\
Black pepper & Piper nigrum & Piperaceae & fruit \\
Cinnamon & Cinnamom umverum & Lauraceae & bark \\
Chilli & Capsicum annuum & Capsicum & fruit \\
Coriander & Coriandrum sativum & Apiaceae & seed \\
Curcuma & Curcuma longa & Zingiberaceae & root \\
Curry & $/$ & $/$ & $/$ \\
Ginger & Zingiber officinale & Zingiberaceae & root \\
Sesame & Sesamum indicum & Pedaliaceae & seed \\
Star anise & Illicium verum & Schisandraceae & fruit shell \\
\hline
\end{tabular}


Sampling and sample preparation

Ten samples of spices (Table 2) found on Serbian territory were taken for the analysis. The preparation of the samples was carried out by wet digestion. A $0.1 \mathrm{~g}$ of the spice mass is overflowed with $1 \mathrm{~cm}^{3}$ of $65 \%$ nitric acid (Centrohem, Serbia) and left for $24 \mathrm{~h}$ in a digester for wet digestion. Before ICP-OES analysis, all samples were diluted with distilled water purified by Fisher Chemical (HPLC grade) to the volume of $10 \mathrm{~cm}^{3}$ and filtrated by cellulose filters $(0.45 \mu \mathrm{m})$.

\section{Analysis of samples}

The quantitative analysis of all samples was performed on ICP-OES (Inductively Coupled Plasma - Optical Emission Spectrometry, ARCOS FHE12, SPECTRO, Germany), according to the manufacturer's instructions. The instrument conditions and determined parameters are given in Table 3.

Table 3. Operating conditions for ICP-OES analysis.

\begin{tabular}{cc}
\hline Plasma Power (W) & 1400 \\
Gas flow (L/min) & 13 \\
-Coolant & 0.80 \\
-Auxiliary & Cross flow \\
Nebulizer type & 0.95 \\
Nebulizer flow rate (L/min) & 30 \\
Pump speed & 0 \\
Stabilization time (s) & 3 \\
Number of probes for each & axial \\
measuring & \\
Plasma observation &
\end{tabular}

\section{Results and discussion}

The content of $\mathrm{Ag}, \mathrm{Al}, \mathrm{B}, \mathrm{Ba}, \mathrm{Bi}, \mathrm{Ca}, \mathrm{Cd}, \mathrm{Co}, \mathrm{Cr}, \mathrm{Cu}$, $\mathrm{Fe}, \mathrm{In}, \mathrm{K}, \mathrm{Li}, \mathrm{Mg}, \mathrm{Mn}, \mathrm{Na}, \mathrm{Ni}, \mathrm{Pb}, \mathrm{Sr}, \mathrm{Tl}$ and $\mathrm{Zn}$ was investigated in 10 samples of spices that were found on the Serbian market. Detected amounts of elements were compared between all the taken samples, as well as with the literature data. The obtained results from this study are presented in Table 4.

Calcium, potassium, magnesium and sodium are highly cationic macroelements and may be readily taken up by the body. In the group of macroelements, the calcium content in spices was the highest, $182.3-3968.79 \mathrm{mg} / \mathrm{kg}$ (Table 4). The obtained calcium concentrations were in accordance with the literature data [12,17,19-21]. Kumaravel and Alagusundaram (2014) investigated the spices from the Indian market and detected $\mathrm{Ca}$ in the concentrations of $243.2-1353.0 \mathrm{mg} / \mathrm{kg}$ [19]. Analogously, Bouba and collaborators (2012) detected $\mathrm{Ca}$ in the concentrations of $62-1594 \mathrm{mg} / \mathrm{kg}$ in spices found on the Cameroon market [21]. On the other side, high calcium concentrations in spices from Southeastern Nigeria have not been recorded. Ujowundu and collaborators (2011) have recorded calcium concentrations in spices in the range of $1.73-77.25 \mathrm{mg} / \mathrm{kg}$ [20].

After calcium, the highest concentration is detected for potassium (19.69-447.65 mg/kg, Table 4). Compared to the potassium presence in spices found on the Indian market (90.4 to $887.8 \mathrm{mg} / \mathrm{kg}$ ) [19], the potassium amount in our study was significantly lower. The recommended daily intake of potassium varies from 0.4 to 4.7 $\mathrm{g}$ depending on the age and gender [22]. Potassium is significant for the acid-base balance in the body, as well as osmotic pressure, and the nerve impulse transmission of the muscle contraction. It has an impact on the carbohydrate metabolism and a membrane transport as well [23].

In the body, sodium is the most common cation that participates in the water metabolism, the contraction of muscles and allows the transfer of carbon - dioxide to the lungs [24,25]. The sodium content in spices was also considerable (37.68-111.36 mg/kg, Table 4).

Magnesium was found in the concentration range from 4.08 to $34.12 \mathrm{mg} / \mathrm{kg}$. The recorded concentrations of magnesium in the spice samples found on Indian (5.7 and $287.2 \mathrm{ppm}$ ) and Southeastern Nigeria markets $(19.17$ to $261 \mathrm{mg} / \mathrm{kg})[19,20]$, were higher compared to the results from this study. Magnesium participates in the regulation of the protein synthesis, blood pressure and muscle and nerve function $[24,25]$. Also, magnesium is included in the active transport across the cell membrane, which is an important process for conducting nerve impulses and a normal heart rhythm. The recommended daily intake of $\mathrm{Mg}$ for adults is about $400 \mathrm{mg}$ [26].

Zinc belongs to the group of microelements and it is essential for the normal function of the brain and biomembranes, as well as for the treatment of mental disorders (e.g. schizophrenia). Also, it is necessary for the metabolism of proteins and carbohydrates, the prostate function and many other biological functions. Zinc is required for DNA synthesis, and plays a major role in the development and functioning of reproductive organs. In addition, zinc is an essential oligoelement that is important for the membrane stabilization and the activity of metalloenzymes (alkaline phosphatase, alcohol dehydrogenase, carbonic anhydrase, lactate dehydrogenase, superoxide dismutase as well as RNA and DNA polymerases [23]. A detected amount of zinc in this study was between 1.49 and $4.64 \mathrm{mg} / \mathrm{kg}$ (Table 4). In investigations of spices carried out in Southeastern Nigeria a detected amount of zinc was between 0.01 to $0.63 \mathrm{mg} / \mathrm{kg}$ [20], while in Indian spices a detected zinc amount was in the range of $1.11-2.57 \mathrm{mg} / \mathrm{kg}$ [19]. This indicates that the presence of zinc in spices from our market is significantly higher. This is a positive factor because recent data indicate that the lack of this vital element is common in $48 \%$ of all global population [27]. A recommended daily intake of zinc for adults is between $12-15 \mathrm{mg}$ (WHO, 1989).

The presence of iron in this study was detected in the range of $1.04-11.72 \mathrm{mg} / \mathrm{kg}$ (Table 4). Iron is responsible for the activity of some enzymes that generate energy. Compared to other investigations, iron in this study was 
detected in significantly lower amounts. In spice samples found on Southeastern Nigeria [20] and Indian [19] markets, iron was detected in the concentration range of $4.8-192.7 \mathrm{mg} / \mathrm{kg}$ and $1.69-17.87 \mathrm{mg} / \mathrm{kg}$, respectively. Bouba and collaborators (2012) recorded the presence of iron (5.9-206.4 mg/kg) in coffee samples found on Cameroon market [21].

Copper, along with vitamin C and zinc, is responsible for maintaining the elasticity of fibers, which provides a better skin structure support. The lack of copper has the effect of anemia, hair depigmentation and bones deformities. According to $\mathrm{WHO}$, the recommended daily dosage of copper is $1 \mathrm{mg}$ [22]. The diet that is deficient in particular essential elements as $\mathrm{Zn}, \mathrm{Fe}$ and $\mathrm{Cu}$ can enhance the accumulation of some toxic metals as $\mathrm{Cd}$ or $\mathrm{Pb}$ [28], which further can influence trace element metabolism [28]. The presence of copper in spice samples was detected in the concentration range of 0.51 to 11.76 $\mathrm{mg} / \mathrm{kg}$ (Table 4). In edible plants, the maximum permissible copper limit set by WHO is $3.00 \mathrm{mg} / \mathrm{kg}$ [30]. Based on this recommendation, three spice samples analysed in this study possess copper over the allowable limit (star anise, cinnamon, coriander). On the other hand, China and Singapore regulations allow copper in the concentration of $20 \mathrm{mg} / \mathrm{kg}$ and $150 \mathrm{mg} / \mathrm{kg}$, respectively [12]. Kumaravel and Alagusundaram (2014) have reported copper amounts in spices between 0.195 and $2.581 \mathrm{mg} / \mathrm{kg}$ [19], while Ujowundu and collaborators (2011) detected copper in the range of 1.93 to $9.84 \mathrm{mg} / \mathrm{kg}$ [20]. The lowest copper concentrations were recorded in the spices from the Cameroon market $(0.01$ and $0.37 \mathrm{mg} / \mathrm{kg})$ [21].

Manganese is important for bone formation, lipid metabolism, the energy production and the synthesis of nucleotides. In this investigation, the obtained values for manganese were in the range of $0.07-6.25 \mathrm{mg} /$ kg. Similarly, Kumaravel and Alagusundaram (2014) detected manganese in Indian spices in the concentration of $0.67-5.73 \mathrm{mg} / \mathrm{kg}$ [19]. On the other side, manganese was detected in a significantly higher concentration in the spice samples from the Cameroon market ( 0.7 to $20.5 \mathrm{mg} / \mathrm{kg}$ ) [21].

The permissible $\mathrm{Mn}$ limit in edible plants set by $\mathrm{FAO} /$ WHO (1984) is $2 \mathrm{mg} / \mathrm{kg}$ [30]. This indicates the fact that all plants can accumulate manganese above this limit, as it was detected in star anise and cardamom spices (Table 4).

Heavy metals belong to a special group of elements classified as the most dangerous inorganic environment pollutants. They are non-biodegradable with the tendency towards bioaccumulation and expression of toxic effects even at a very low concentration. Some heavy metals are among the group of trace microelements because even they are toxic in higher concentrations. At lower concentrations they are necessary for the plant and other living organisms ' growth and development. The accumulation of heavy metals in plants depends not only on the total content in the soil, but also on the kind of affinity, as well as individual and interactive effects of different soil properties [31].

Aluminium is included as a cofactor in the guanine nucleotide binding which is necessary for the metabolism of protein. The presence of aluminium in spice samples was detected at $0.0-10.78 \mathrm{mg} / \mathrm{kg}$ (Table 4). The increased content of this element in patient kidneys can significantly damage the skeleton due to the negative impact on the process of the bone formation, leading to the occurrence of osteomalacia [32]. Other heavy metals detected in no significant amounts in the spice samples are $\mathrm{Pb}$ and $\mathrm{Ni}$, while the presence of $\mathrm{Cd}$ was detected just in Cinnamon spice in the quantity safe for the health.

Table 4. Spices minerals content ( $\mathrm{mg} / \mathrm{kg}$ ) obtained by ICP-OES method

\begin{tabular}{|c|c|c|c|c|c|c|c|c|c|c|}
\hline Elements & Curcuma & Star anise & Cinnamon & Ginger & Coriander & Cardamom & Sesame & $\begin{array}{c}\text { Black } \\
\text { pepper }\end{array}$ & Chilli & Curry \\
\hline $\mathrm{Ag}$ & 0.00 & 0.00 & 0.00 & 0.00 & 0.00 & 0.00 & 0.00 & 0.00 & 0.00 & 0.00 \\
\hline $\mathrm{Al}$ & 1.83 & 0.00 & 0.06 & 6.50 & 10.78 & 2.19 & 1.13 & 0.04 & 2.59 & 1.66 \\
\hline B & 0.00 & 0.27 & 0.92 & 3.22 & 5.52 & 0.86 & 1.09 & 1.44 & 1.95 & 0.17 \\
\hline $\mathrm{Ba}$ & 0.84 & 1.00 & 5.10 & 2.43 & 10.10 & 1.98 & 1.19 & 1.12 & 1.07 & 0.86 \\
\hline $\mathrm{Bi}$ & 0.47 & 0.51 & 0.79 & 0.48 & 0.62 & 0.57 & 0.81 & 0.59 & 2.19 & 0.47 \\
\hline $\mathrm{Ca}$ & 182.25 & 995.13 & 592.53 & 2030.90 & 1577.44 & 874.23 & 361.28 & 3968.79 & 534.44 & 502.66 \\
\hline $\mathrm{Cd}$ & 0.00 & 0.00 & 0.02 & 0.00 & 0.00 & 0.00 & 0.00 & 0.00 & 0.00 & 0.00 \\
\hline Co & 0.00 & 0.00 & 0.00 & 0.00 & 0.00 & 0.00 & 0.00 & 0.00 & 0.00 & 0.00 \\
\hline $\mathrm{Cr}$ & 0.00 & 0.00 & 0.00 & 0.00 & 0.00 & 0.00 & 0.00 & 0.00 & 0.00 & 0.00 \\
\hline $\mathrm{Cu}$ & 1.58 & 11.00 & 11.76 & 1.67 & 5.35 & 1.33 & 2.03 & 2.58 & 1.40 & 0.51 \\
\hline $\mathrm{Fe}$ & 1.08 & 9.49 & 3.91 & 8.01 & 11.72 & 3.25 & 2.98 & 2.69 & 3.55 & 1.05 \\
\hline In & 0.38 & 1.94 & 0.77 & 0.60 & 0.62 & 1.27 & 0.48 & 0.53 & 0.44 & 0.50 \\
\hline $\mathrm{K}$ & 19.69 & 74.22 & 28.70 & 277.52 & 97.51 & 447.65 & 32.40 & 112.16 & 305.12 & 48.49 \\
\hline $\mathrm{Li}$ & 0.09 & 0.12 & 0.11 & 0.16 & 0.12 & 0.12 & 0.10 & 0.13 & 0.26 & 0.08 \\
\hline $\mathrm{Mg}$ & 4.08 & 10.90 & 4.68 & 34.12 & 11.01 & 14.41 & 25.19 & 20.21 & 16.65 & 7.66 \\
\hline $\mathrm{Mn}$ & 0.07 & 6.26 & 1.46 & 0.61 & 0.72 & 3.65 & 0.07 & 0.21 & 0.10 & 0.56 \\
\hline $\mathrm{Na}$ & 39.37 & 54.97 & 48.43 & 111.36 & 57.77 & 46.89 & 63.80 & 67.39 & 57.70 & 37.68 \\
\hline $\mathrm{Ni}$ & 0.00 & 0.39 & 0.11 & 0.00 & 0.00 & 0.00 & 0.00 & 0.00 & 0.00 & 0.00 \\
\hline $\mathrm{Pb}$ & 0.16 & 0.37 & 0.31 & 0.14 & 0.12 & 0.08 & 0.17 & 0.13 & 0.16 & 0.08 \\
\hline $\mathrm{Sr}$ & 0.11 & 0.31 & 1.46 & 0.82 & 0.93 & 0.33 & 0.31 & 0.61 & 0.22 & 0.42 \\
\hline $\mathrm{TI}$ & 0.00 & 0.00 & 0.00 & 0.00 & 0.00 & 0.00 & 0.00 & 0.00 & 0.00 & 0.00 \\
\hline $\mathrm{Zn}$ & 1.49 & 4.01 & 4.58 & 1.95 & 2.33 & 3.01 & 4.64 & 3.26 & 1.71 & 1.53 \\
\hline
\end{tabular}




\section{Conclusion}

The results in this study confirm that the following elements: Ag, Al, B, Ba, Bi, Ca, Cd, Co, Cr, Cu, Fe, In, K, $\mathrm{Li}, \mathrm{Mg}, \mathrm{Mn}, \mathrm{Na}, \mathrm{Ni}, \mathrm{Pb}, \mathrm{Sr}, \mathrm{TI}$ and $\mathrm{Zn}$ can be successfully estimated in the spice samples by using ICP-OES method of analysis. The use of ICP-OES provides a simpler, effective, faster, and less contamination procedure for determining the nutritive profile of the spice and spice extracts. The obtained results showed that the analysed spices are a good source of calcium, sodium, potassium and magnesium and therefore represent an important human nutrient source. From macroelements group, the most common element was calcium (182.25-3968.79 $\mathrm{mg} / \mathrm{kg}$ ), almost $83 \%$, while the lowest was magnesium (in the range of $4.08-34.12 \mathrm{mg} / \mathrm{kg}$ ), about $1 \%$. The obtained results of nontoxic, as well as toxic elements in spices confirmed that the analysed spices represent no risk for the human health if they are taken in a limited quantity. Of all heavy metals, the presence of aluminium was detected in the highest amount of $0.0-10.78 \mathrm{mg} / \mathrm{kg}$. A human need for spices is very few grams per day, and in that quantity there is no risk of their use in the food stuff. Anyhow, spices and herbs used in food may contain some toxic metals in a relatively high level, and therefore they should be under continuous monitoring.

\section{Acknowledgements}

This work was supported by the Ministry of Education, Science and Technological Development of the Republic of Serbia under the Project on Development of Technology number TR-34012.

\section{References}

[1] U. R. Susheela, Handbook of Spices, Seasoning, and Flavorings, TECHNOMIC Publishing Co., Inc., Lancaster, 2000, p. 329.

[2] J. Bitting, P. W. Sherman, Antimicrobial Functions of Spices-Why Some Like It Hot, Quarterly Review of Biology, 73(1) (1998) 3 - 49.

[3] C. M. F. Mbofung, J. M. Gee, J. D. Knight, Fatty Acid Profile of Some Cameroonian Spices, Journal of the Science of Food and Agriculture, 66(2) (1994) 213 - 216.

[4] V. Singh, A. N. Garg, Availability of essential trace elements in Indian cereals, vegetables and spices using INAA and the contribution of spices to daily dietary intake, Food Chemistry, 94(2006) 81 - 89.

[5] A. Ajasa, M. O. Bello, A. O. Ibrahim, I. A. Ogunwande, N. O. Olawore, Heavy trace metals and micronutrients status in herbal plants of Nigeria. Food Chemistry, 85(2004) 67-71.

[6] A. A. Barakat, A. O. Maslat, M. M. AL-Kofahi, Ele-ment Analysis and Biological Studies on Ten Oriental Spices Using XRF and Ames Test, Journal of Trace Element Medicine Biology, 17(2)(2003) 85-90.

[7] H. R. H. Takruri, A. F. M. Dameh, Study of the Nu-tritional Value of Black Cumin Seeds (Nigella sativa L), Journal of the Science of Food and Agriculture, 76(3)(1998) 404-410.
[8] Z. Krejpcio, E. Krol, S. Sionkowski, Evaluation of Heavy Metals Contents in Spices and Herbs Available in the Polish Market,Polish Journal of Environmental Studies, 16(1) (2007) 97-100.

[9] I. Hinneburg, H. J. Damien, R.Hiltunen, Antioxidant activities of extracts from selected culinary herbs and spices,Food Chemistry, 97 (2006)122 - 129.

[10] E. J. Underwood, N. F. Suttle, In The Mineral Nutrition of Livestock, 3rd Ed. CABI Publishing, London, 1999.

[11] O. C. Enechi, S. Amarachi, P. C. U. Okechukwu, Concentration of iodine and some environmental goitrogens in two selected water bodies - Adada and Akoru in Nsukka, Enugu State, Nigeria, African Journal of Biotechnology, 13(44) (2014) 4215 - 4219.

[12] F. Inam, S. Deo, N. Narkhede, Analysis of minerals and heavy metals in some spices collected from local market, IOSR Journal of Pharmacy and Biological Sciences (IOSR-JPBS), 8(2) (2013) 40-43.

[13] J. Gilbert, Analysis of food contamination. Elsevier App. Sci. Pups., London,1984.

[14] F. M. Oehme, Toxicity of heavy metals in the environment, Marcel Dekker, New York, 1989.

[15] C. Gopalan, B. V. Ramasastri, S. C. Balasubramanian, B S. Narsinagarao, Y. G. Deosthale, K. C. Pant, Nutritive value of Indian foods, Indian National Institute of Nutrition, Hyderabad, 1999,p. 156.

[16]J. S. Pruthi, Quality assurance in spices and spice products, modern methods of analysis, Allied Publishers Ltd., New Delhi,1999.

[17] P. Ila, P. Jagam, Multielement analysis of food spices by instrumental neutron activation analysis. Journal of Radioanalytical Chemistry, 57 (1980) 205 - 210.

[18] A. A. K. Abou-Arab, M. A. Abou Donia, Heavy metals in Egyptian spices and Medicinal plants and the effect of processing on their levels, Journal of Agricultural Food Chemistry, 48 (2000) 2300 - 2304.

[19] S. Kumaravel, K. Alagusundaram, Determinationof Mineral Content in Indian Spices by ICP-OES, Oriental Journal of Chemistry, 30(2) (2014) 631-636.

[20] C. O. Ujowundu, F. N. Kalu, E. C. Nwosunjoku, R. N. Nwaoguikpe, R. I. Okechukwu, K. O. Igwe, lodine and inorganic mineral contents of some vegetables, spices and grains consumed in Southeastern Nigeria, African Journal of Biochemistry Research, 5(2) (2011) 57 - 64.

[21] A. A. Bouba, N. Y. Njintang, H. S. Foyet, J. Scher, D. Montet, C. M. F. Mbofung, Proximate Composition, Mineral and Vitamin Content of Some Wild Plants Used as Spices in Cameroon, Food and Nutrition Sciences, $3(2012) 423-432$.

[22] WHO, Toxicological Evaluation of Certain Food Additives and Contaminants, 33rd Meeting of the Joint FAO/WHO Expert Committee on Food Additives, Geneva, 1989.

[23] D. Veljković, G. N. Vučković, Minerali u ishrani, Hemijski pregled, 51(1) (2010) $14-19$.

[24] H. Marschner, Mineral Nutrition in Higher Plants, Academic Press, London, 1995.

[25] A. V. Barker, D. J. Pilbeam, Handbook of plant nutrition, CRC press, London,2015.

[26] M. P. Guerrera, S. L. Volpe, J. J. Mao, Therapeutic uses of magnesium, American Family Physician, 80(2) (2009) $157-162$.

[27] P. Oteiza, G. Mackenzie, Zinc, oxidant-triggered cell signaling and human health. Molecular Aspect of Medicine, 26 (2005) 245 - 255. 
[28] WHO, Trace elements in humannutrition and health, Geneva, 1996.

[29] M. L. Alonso, F. P. Montaña, M. Miranda, C. Castillo, J. Hernández, J. L. Benedito, Interactions between toxic (As, $\mathrm{Cd}, \mathrm{Hg}$ and $\mathrm{Pb}$ ) and nutritional essential ( $\mathrm{Ca}, \mathrm{Co}, \mathrm{Cr}, \mathrm{Cu}$, $\mathrm{Fe}, \mathrm{Mn}, \mathrm{Mo}, \mathrm{Ni}, \mathrm{Se}, \mathrm{Zn}$ ) elements in the tissues of cattle from NW. Spain, Biometals, 17(4) (2004) 389 - 397.

[30] $\mathrm{FAO} / \mathrm{WHO}$, Contaminants. In Codex Alimentarius, vol. XVII,Edition 1. FAO/WHO, Codex Alimentarius Commision, Rome, 1984.ž

[31] S. Jiwan, A. S. Kalamdhad, Effects of Heavy Metals on Soil, Plants, Human Health and Aquatic Life. International
Journal of Research in Chemistry and Environment, 1(2) (2011) 15-21.

[32] K. J. Martin, E. A. Gonzales, Metabolic Bone Disease in Chronic Kidney Disease, Journal of American Society of Nephrology, 18(2007) 875-885.

\section{Izvod}

\section{ODREĐIVANJE MINERALNOG SADRŽAJA ZAČINA PRIMENOM ICP-OES}

Saša Savić ${ }^{1}$, Sanja Petrović ${ }^{1}$, Mirjana Petronijević ${ }^{2}$, Aleksandra Cvetanović ${ }^{3}$, Živomir Petronijević ${ }^{1}$

${ }^{1}$ Univerzitet u Nišu, Tehnološki fakultet, Leskovac, Srbija

2 Univerzitet u Novom Sadu, Prirodno-matematički fakultet, Novi Sad, Srbija

${ }^{3}$ Univerzitet u Novom Sadu, Tehnološki fakultet, Novi Sad, Srbija

Pod začinima se podrazumevaju svi jestivi delovi biljaka koji se koriste za aromatizovanje ili bojenje hrane, uključujući voće, koren, seme, koru i povrće. Upotreba začina u prošlosti se značajno razlikovala između kultura i zemalja. Ranije, začini su se koristili u medicini, religijskim ritualima, kozmetici i parfimisanju hrane. U poslednje vreme, začini se uglavnom koriste kao preventiva protiv štetnih bakterija ili kao izvori nutritijenata koji su važni za ljudsko zdravlje. U ovoj studiji je ispitivan sadržaj Ag, Al, B, Ba, Bi, Ca, Cd, Co, Cr, Cu, Fe, In, K, Li, Mg, Mn, Na, Ni, Pb, Sr, $\mathrm{TI}$ i Zn u deset uzoraka začina, koji su pronađeni u marketima na teritoriji Srbije. Među analiziranim uzorcima začina su bili: kurkuma, zvezdasti anis, cimet, đumbir, korijander, kardamon, susam, crni biber, čili i kari. Priprema uzoraka je urađena vlažnom digestijom. Koncentracije elemenata nakon digestije su određene primenom optičke emisione spektrometrije sa indukovano spregnutom plazmom (ICP-OES). U svim ispitivanim uzorcima, koncentracija kalcijuma je bila najveća (182.25 - $3968.79 \mathrm{mg} / \mathrm{kg}$ ), oko 83\%. Iz grupe teških metala (kadmijum, bakar, olovo, mangan, nikal i cink) određivanih u ispitivanim uzorcima, najprisutniji je bio aluminijum u opsegu od 0.0 do 10.78 mg/kg, dok su nikal i kadmijum detektovani u malim količinama.
(ORIGINALNI NAUČNI RAD) UDK 664.5:661.8:543.42

KIjučne reči: začini, minerali, ICP-OES 